\title{
Examination on the effectiveness of a glycerol injection at the trigeminal nerve as a basis for the treatment of headshaking in the horse
}

\author{
Judith C. Winter', Verena Haist² and Karsten Feige \\ University of Veterinary Medicine Hanover, Foundation, Clinic for Horses, 30559 Hanover, Germany \\ 2 University of Veterinary Medicine Hanover, Foundation, Department of Pathology, Hanover, Germany
}

Summary: At the moment, therapy of equine idiopathic headshaking is difficult, as there is no adequate treatment for all trigeminal nerve branches available. In humans, trigeminal neuralgia, a similar disease, can be treated by the injection of glycerol into the trigeminal nerve root. The purpose of this study was to develop a minimally invasive injection technique into the trigeminal ganglion and to describe the effects of a glycerol injection. This study was performed on eight neurologically healthy horses. Under general anaesthesia and computer-tomographic guidance, a biopsy needle was moved through the guttural pouch into the trigeminal ganglion. Glycerol (1.6-1.9 ml) was injected into the trigeminal ganglion of one side of the head. Subsequently, the horses were clinically and neurologically examined at planned intervals. After the glycerol injection, the examination was performed every day during the first two weeks, then every other day for the next two weeks and then two times a week. After six weeks, the horses were euthanized and the trigeminal nerve and its surroundings were investigated macroscopically and histologically. A Wilcoxon signed rank test was used for non-normally distributed data. Statistical significance was set at $p<0.05$. The glycerol injection could be accomplished in all of the eight cases. In one horse, severe neurologic signs occurred (increased sensitivity and pruritus at the head and neck on both sides and hypermetric, ataxic movements) which were ascribed to a meningitis in the post mortem examination. Another horse showed neurologic signs (torticollis to the left side, hemi-facial spasm and hyperaesthesia at head and neck on the left side as well as generalized ataxia) for unknown reasons which disappeared after adequate therapy. On both sides, signs of a degenerative neuropathy which were significantly more severe $(p<0.05)$ on the glycerol-treated side were observed. It was concluded that the glycerol injection is practicable in horses. Anatomical differences between horses and humans necessitate a diverging procedure and with respect to this the needle guidance by computed tomography was considered feasible. The degeneration detected in the histopathological examination indicated reduced conductivity of the trigeminal nerve which suggests that a glycerol injection produces the desired effects. As the glycerol injection has been performed only in healthy horses, the actual effect on headshaking horses cannot be verified yet and has to be examined in further investigations. Especially with regard to the fact that so far, no therapy for headshaking in the horse at the trigeminal nerve level exists, the present study can be considered as a basis for a minimally invasive therapy at the trigeminal ganglion.

Keywords: Horse / trigeminal nerve / headshaking / glycerol / neuropathy

\section{Untersuchung zur Wirkungsweise einer Glyzerolinjektion an das Ganglion trigeminale als Grundlage einer Behandlung des Headshakings beim Pferd}

Die Therapie des equinen idiopathischen Headshakings ist derzeit sehr schwierig, da keine Behandlungsmöglichkeit aller drei Äste des Trigeminusnerven zur Verfügung steht. In der Humanmedizin kann eine ähnliche Erkrankung, die Trigeminusneuralgie, durch eine Injektion von Glyzerol an das Ganglion trigeminale behandelt werden. Das Ziel dieser Untersuchung war es, eine minimal invasive Injektionstechnik an das Ganglion trigeminale zu entwickeln und die Folgen einer Glyzerolinjektion in diesen Bereich zu beschreiben. Die Untersuchung wurde an acht klinisch und neurologisch gesunden Pferden durchgeführt. Eine Biopsienadel wurde unter Allgemeinanästhesie und computertomographischer Führung durch den Luftsack in das Ganglion trigeminale geführt. Es wurden zwischen 1.6-1.9 ml Glyzerol in das Ganglion trigeminale einer Kopfseite injiziert. Im Anschluss wurden die Pferde in geplanten Intervallen klinisch und neurologisch untersucht. Die Untersuchung wurde in den ersten beiden Wochen nach der Glyzerolinjektion täglich durchgeführt, anschließend für weitere zwei Wochen alle zwei Tage und schließlich zweimal wöchentlich. Nach sechs Wochen wurden die Pferde euthanasiert und der Trigeminusnerv einschließlich des angrenzenden Gewebes makroskopisch und histologisch untersucht. Ein Wilcoxon signed rank Test wurde für nicht normalverteilte Daten genutzt. Das statistische Signifikanzniveau wurde bei $p<0.05$ festgelegt. Die Glyzerolinjektion konnten in allen acht Fällen durchgeführt werden. Bei einem Pferd traten schwerwiegende neurologische Störungen auf (erhöhte Sensitivität und Juckreiz beidseits an Kopf und Hals sowie hypermetrische, ataktische Bewegungen), die in der postmortalen Untersuchung einer Meningitis zugeordnet werden konnten. Ein anderes Pferd zeigte aus ungeklärter Ursache ebenfalls neurologische Symptome (Tortikollis zur linken Seite, hemifazialer Spasmus und Hyperästhesie an Kopf und Hals der linken Seite sowie generalisierte Ataxie), die nach entsprechender Therapie verschwanden. Der Trigeminusnerv und seine Äste zeigten auf beiden Kopfseiten eine degenerative Neuropathie, die auf der behandelten Seite signifikant $(p<0.05)$ stärker ausgeprägt war. Eine Glyzerolinjektion an das Ganglion trigeminale ist beim Pferd durchführbar. Verschiedene anatomische Gegebenheiten bei Mensch und Pferd bedingen zwangsläufig einige Unterschiede in der Vorgehensweise. Der Kanülenverlauf ist beim Pferd schwieriger zu kontrollieren, da die Möglichkeit der fluoroskopischen Kontrolle nicht gegeben ist. Die CT-geleitete Steverung der Kanüle beim Pferd ist praktikabel. Die degenerativen Veränderungen, die in der histopathologischen Untersuchung festgestellt wurden, implizieren eine reduzierte Reizweiterleitung des Trigeminusnerven. Dies spricht dafür, dass die Glyzerolinjektion den gewünschten Effekt erzielt. Da die Glyzerolinjektion bisher nur an gesunden Pferden vorgenommen wurde, ist die Wirkung, das heißt eine Linderung des Headshakings, nicht überprüfbar. Vor allem im Hinblick darauf, dass zurzeit keine erfolgreiche Behandlungsmethode für das Headshaking beim Pferd existiert, ist die vorliegende Untersuchung als Grundlage für eine direkte, minimal invasive Therapie am Ganglion trigeminale zu sehen.

Schlüsselwörter: Pferd / Trigeminus / Kopfschütteln / Glycerol / Neuropathie

Correspondence: Dr. Judith C. Winter, Free University of Berlin, Clinic for Horses, Oertzenweg 19b, 14163 Berlin, Germany, E-Mail: judith-winter@fu-berlin.de

Citation: Winter J. C., Haist V., Feige K. (2014) Examination on the effectiveness of a glycerol injection at the trigeminal nerve as a basis for the treatment of headshaking in the horse. Pferdeheilkunde 30, 252-262 


\section{Introduction}

Idiopathic headshaking in the horse is a complex and severe disease with mostly insufficient treatment options. Clinical signs are similar to those of trigeminal neuralgia in humans. Therefore, a neuritis or neuralgia of the trigeminal nerve is considered a possible aetiopathology for equine headshaking (Cook 1980, Newton et al. 2000). Trigeminal neuralgia in humans is a painful, mostly unilateral affection of the face concerning one or more branches of the trigeminal nerve. In most cases, it is caused by a vascular compression syndrome with a pathological vessel-nerve-contact (Paulus et al. 2003). The pulsating artery impairs the myelin sheaths of the trigeminal nerve which leads to segmental demyelination and, in consequence, to ephaptic communication in within the nerve fibres (Barker et al. 1996). The electric potential jumps from myelinated sensitive fibres to the non-myelinated nociceptive fibres, causing a pulsing pain (Stienen et al. 2010). There are different medical and surgical treatment options for trigeminal neuralgia in humans which usually lead to mechanical or chemical impairment of the A $\delta$ - and C-fibres of the trigeminal nerve and thus decrease the perception of pain (Pannullo and Lavyne 1996). Hakanson et al. (1981) describes the retrogasserian glycerol rhizotomy in humans as a technique for percutaneous puncture of the gasserian ganglion (trigeminal nerve root) under fluoroscopic guidance and application of sterile glycerol. According to a study including 1174 patients, the success rate is $95 \%$ with a recurrence rate of up to $40 \%$ after 17 months of treatment (Kondziolka and Lunsford 2005). The glycerol leads to a degeneration of the treated nerve root and therefore to a reduced conductivity. As an adverse reaction, up to $50 \%$ of the patients suffer from a temporary hypaesthesia and hypoalgesia in the affected part of the face (Paulus et al. 2003). Even if there are no pathologic vessel-nerve-contacts described in the horse, a trigeminal disorder could be the reason for idiopathic headshaking. The mandibular branch of the trigeminal nerve can only infrequently be related to headshaking. Usually, the infraorbital branch of the maxillary nerve and the ethmoidal branch of the ophthalmic nerve are affected (Newton et al. 2000). Sclerosis of the ethmoidal branch of the ophthalmic nerve after injection of phenol was reported by Newton et al. (2000) and was successful in three out of five horses. Roberts et al. (2009) performed a caudal compression of the infraorbital nerve with platinum coils in 24 horses with idiopathic headshaking and reported a success rate of $59 \%$ after one surgical treatment. Disadvantages of this treatment were a high rate of automutilation $(45.8 \%)$ and the selective compression of the infraorbital nerve (Roberts et al. 2009). Therefore, this treatment could be successful if the painful stimulus arises within the infraorbital nerve itself and fail if it originates at a more proximal site, closer to the trigeminal nerve root. The intention of this study was to develop a minimally invasive injection technique into the trigeminal ganglion as a basis for a treatment option of all branches of the trigeminal nerve.

\section{Materials and Methods}

Materials

Eight clinically and neurologically healthy horses were included in the present study. There were four stallions, one gel- ding and three mares. Five of the horses were Hanoverian Warmbloods, one was an Arabian and two horses were of unknown breed. Their median age was $21.4( \pm 6.91)$ years, the median body weight (bwt) was 497.5 ( \pm 90$) \mathrm{kg}$.

\section{Preoperative proceedings and anaesthesia}

The procedure was performed under general anaesthesia. The horses were sedated with the $\alpha 2$-Agonist xylazine (Xylazin $2 \%)^{a}(0.08 \mathrm{mg} / \mathrm{kg}$ bwt i.v. $)$, anaesthesia was induced with ketamine (Narketan) ${ }^{b}(2.2 \mathrm{mg} / \mathrm{kg}$ bwt i.v.), and Diazepam (Diazep AbZ 10 mg Ampullen)c (0.04 mg/kg bwt i.v.) and maintained with isoflurane (Isofluran) in $100 \%$ oxygen according to effect. During anaesthesia, heart and circulation patterns (heart rate, respiratory rate, electrocardiographic abnormalities and intra-arterial blood pressure) were monitored (Vet.Tec. Model JAVC-2000)e and the horses were ventilated if necessary. The median arterial blood pressure was measured using a pressure transducer (PD23ID) ${ }^{f}$. To stabilize blood pressure, horses received lactated Ringer's (Rin-

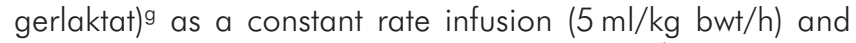
dobutamine (Dobutamin ratiopharm $250 \mathrm{mg}$ ) ${ }^{\mathrm{h}}$ as required $(1.2-3 \mu \mathrm{g} / \mathrm{kg} \mathrm{bwt} / \mathrm{min})$. Horses were placed in dorsal recumbency for the procedure; the head was positioned symmetrically and fixed with a vacuum cushion. The skin on the ventral part of the head from the facial vessel notch to the larynx was prepared antiseptically and the guttural pouch was flushed with $40 \mathrm{ml}$ of a $1 \%$ povidone-iodine solution (Braunol)g.

\section{Surgical technique}

The caudal aspect of the mandibular branch and the mandibular body were used for orientation. For planning the direction of the biopsy needle, an 18 gauge needle (Sterican) ${ }^{g}$ was placed two centimetres cranial to the caudal aspect of the mandibular branch, approximately one centimetre axial to the mandibular body and at a right angle to an imaginary line applied parallel to the mandibular body. It was placed lateral to the Vena linguofacialis. Another 18 gauge needle was placed one and a half centimetres more rostral and medial to the Vena linguofacialis. A computed tomography (CT) (Phillips Tomoscan)i was performed with these needles in place and the final position for insertion of the puncture needle (Chiba-Biopsienadel)i was adjusted. The needle then inserted through the guttural pouch and was placed approximately eighteen centimetres deep next to the Arteria carotis interna in front of the foramen lacerum. Subsequently, the needle was moved one and a half centimetres forward into the trigeminal ganglion. Thereafter, the position was controlled again by CT (Fig. 1) and the glycerol (Glycerinum anhydriacum) ${ }^{\mathrm{k}}(1.6-1.9$ $\mathrm{ml}$ ) was injected on one side of the head which was randomly chosen. The contralateral side remained untreated and served as a control. If the puncture needle had to be repositioned after CT control, this was counted as a new attempt.

\section{Pre- and post-operative care}

All horses were treated with antibiotics and non-steroidal antiinflammatory drugs for at least five days. They received ben- 
zylpenicillin (Penicillin grünenthal 10 Millionen I.E.)' $(20.000$ $\mathrm{IU} / \mathrm{kg}$ bwt i.v. q. $6 \mathrm{~h}$ ) and gentamicin (Genta $100 \mathrm{mg} / \mathrm{ml})^{a}$ (6.6 mg/kg bwt i.v. q.d.) on the day of surgery and cefquinome sulfate (Cobactan 4,5\%)i (1 mg/kg bwt i.m. q.d.) for the next four days. Furthermore, all horses were treated with flunixin (Flunidol RPa, Finadyne Paste $\left.{ }^{\mathrm{m}}\right)(1.1 \mathrm{mg} / \mathrm{kg}$ bwt i.v. q.d. for the first two days, then $1.1 \mathrm{mg} / \mathrm{kg}$ bwt p.o. q.d. for four more days). All horses were clinically and neurologically examined before the glycerol treatment. After the glycerol injection, the examination was performed every day during the first two weeks, then every other day for the next two weeks and then twice weekly. Six weeks after the glycerol treatment, all horses were euthanized with pentobarbital (Release) ${ }^{n}(0.08$ $\mathrm{g} / \mathrm{kg}$ bwt i.v.).

\section{Post mortem examination}

A macroscopic examination of the guttural pouch and the point of the needle entrance into the cranial cavity were performed on all horses. The trigeminal nerve root and all efferent nerves were macroscopically and histologically examined. For the histological classification, samples were taken from eight preassigned locations of the trigeminal nerve root and its efferent nerves. Sample 1 was taken from the pons, sample 2 from the nucleus of the trigeminal nerve root, sample 3 from the nerve root itself and samples 4-8 from the branches (ophthalmic, maxillary and infraorbital nerve). The samples were stained with hematoxylin-eosin (HE) and selected samples additionally with Luxol-Fast-Blue according to

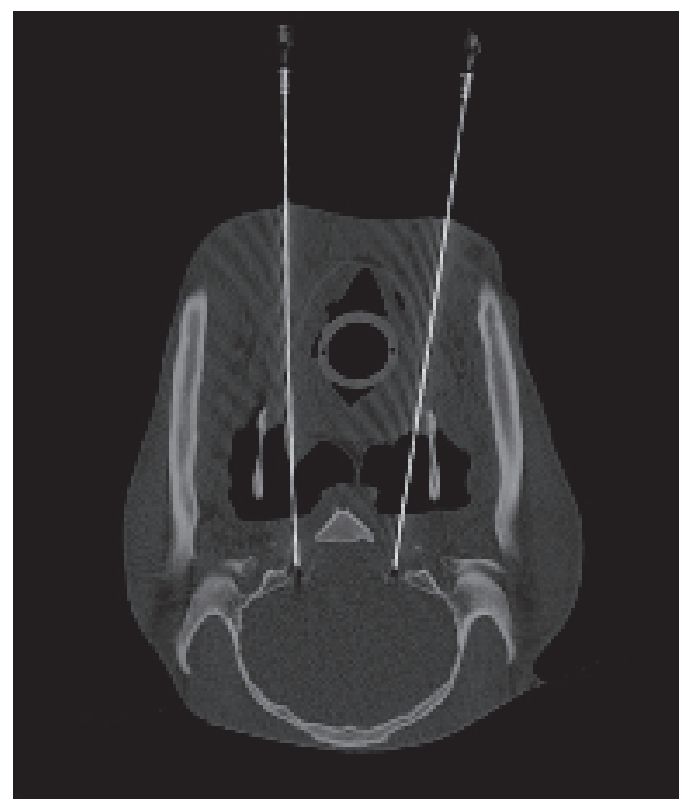

Fig. 1 Transversal computer tomographic image of the correct position of the puncture needles for bilateral glycerol injection. Both needles pass the hyoid bone on the medial side, cross the guttural pouches and enter the cranial cavity via the foramen lacerum. Both needlepoints are located at the ganglion trigeminale. Slight fluid accumulation in both guttural pouches can be seen.

Computertomographischer Querschnitt. Gezeigt wird die korrekte Position der Punktionsnadeln für eine beidseitige Glyzerolinjektion in das Ganglion trigeminale. Beide Nadeln passieren das Zungenbein auf der medialen Seite, durchqueren den Luftsack und dringen durch das Foramen lacerum in die Schädelhöhle ein. Beide Nadelspitzen befinden sich im Ganglion trigeminale. Eine leichte Flüssigkeitsansammlung in den Luftsäcken ist sichtbar.
Romeis 1989. Samples with sporadic dilated myelin sheaths were scored as showing mild changes (Score 2), samples with more dilated myelin sheaths, axon swelling and single myelinophages as moderate (Score 4) and those with a great number of changes like digestion chambers were scored as severe (Score 6). Intermediate scoring was possible (Score 1: no to minimal changes; Score 3: minimal to moderate changes; Score 5: moderate to severe changes). If no changes occurred, the score was 0 . In all horses with postoperative complications $(n=2)$, a complete post mortem examination was performed in addition.

\section{Statistics}

Data was analysed using a statistical software package (SAS). Data is reported as mean \pm s.d. for normally distributed data and median (range) for non-normally distributed data. A Wilcoxon signed rank test was used for non-normally distributed data, results were considered statistically significant if $\mathrm{p}<0.05$.

\section{Results}

The injection of glycerol was performed on the left side of the head in five out of eight cases and on the right side of the head in 3 out of eight cases. The trigeminal ganglion was reached in all eight cases, with one to seven (mean $4 \pm 1.9$ ) attempts being necessary to achieve this. In six cases, the needle was inserted lateral to the linguofacial vein, in two cases medial to it. In all cases, the needle had to be advanced medial to the hyoid bone. In three cases, bleeding was caused when entering the medial compartment of the guttural pouch. During the application of glycerol, in two horses, the needle slid a few millimetres backwards. The needle was repositioned and in both horses an additional $0.5 \mathrm{ml}$ of glycerol were administered. Haemorrhage out of the cranial cavity into the guttural pouch was induced in seven of the eight cases after removal of the needle, as seen via endoscopic and CT control.

\section{Anaesthesia and blood pressure development}

No complications occurred during anaesthesia. While injecting glycerol, blood pressure rose for several seconds in six out of eight horses. The mean arterial blood pressure before injection was $79 \pm 9.7 \mathrm{mmHG}$ and during injection $111 \pm 28.2 \mathrm{mmHG}$. Blood pressure was back to the normal level after a few seconds and no treatment was initiated. In five horses, muscle fasciculations in the region of the masseter and nostrils were observed for a few seconds during glycerol application.

\section{Postoperative development}

Horse 2 showed a rectal temperature of $41^{\circ} \mathrm{C}$ and a slightly elevated heart and breathing rate two days after injection. On day three, it developed neurologic symptoms with an increased sensitivity and pruritus at the head and neck on both sides and hypermetric, ataxic movements. The horse was treated 
symptomatically, but the condition did not improve and it was euthanized on day eight after surgery.

Directly after surgery, horse 7 showed neurologic symptoms comprised of torticollis to the left side, hemifacial spasm and hyperaesthesia at head and neck on the left side as well as generalized ataxia. In this horse, the glycerol injection was performed on the left side. It was also treated symptomatically and did not show any neurologic symptoms after ten days of treatment. No neurologic symptoms or other clinically noticeable problems occurred in the other six horses.

\section{Post mortem examination}

In horse 2, a focal accentuated suppurative meningoencephalitis was diagnosed; no bacteria could be seen histologically. In horse 7, no special findings which could explain the neurologic symptoms were detected. The macroscopic examination of the guttural pouches, injection sites and trigeminal ganglia did not show any differences between glycerol-treated and contralateral sides in any of the horses.

\section{Histology}

In two cases, mild changes occurred (Score 2, horses 6 and $8)$; in one case they were mild to moderate (Score 3, horse $3)$; in two cases they were moderate (Score 4, horses 1 and 4) and in two cases severe changes (Score 6, horse 5 and 7) in terms of a degenerative neuropathy could be seen on the glycerol-treated side (Fig. 2). The contralateral side showed no $(n=2)$ or mild $(n=5)$ degenerative changes (Score 0-2). The neurologic changes on the glycerol-treated side (11; $6-32)$ were significantly $(p<0.05)$ more severe than on the contralateral side $(2 ; 0-4)$.

Horse 2 could not be scored due to the meningitis. A mild to moderate lymphohistiocytic to suppurative diffuse meningitis of the cerebrum and cerebellum was diagnosed.

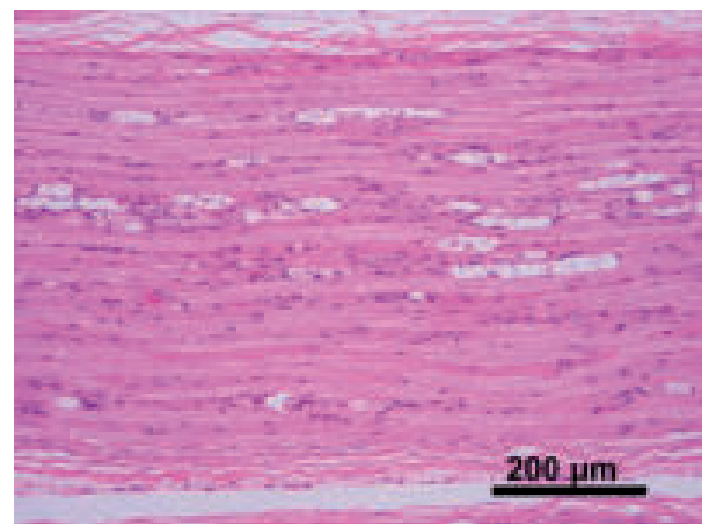

Fig. 2 A haematoxylin \& eosin (HE) stained slide from the infraorbital nerve (localization 5) at x10 magnification. It shows severe degeneration after glycerol injection with severely dilated myelin sheaths, fragments of degenerated axons, myelinophages and digestion chambers.

Ein Hämatoxylin \& Eosin (HE) gefärbtes histologisches Präparat des Infraorbitalnerven (Lokalisation 5) in zehnfacher Vergrößerung. Es zeigt eine hochgradige Degeneration nach Glyzerolinjektion mit hochgradig dilatierten Myelinscheiden, Fragmenten degenerierter Axone, Myelinophagen und sogenannten "digestion chambers".

\section{Discussion}

In the context of this study, the practicability of the glycerol injection, the adverse effects and the induced histologic changes of the trigeminal ganglion were of interest. In human medicine, different surgical treatment regimens for trigeminal neuralgia exist. However, for various reasons, not all of them are practicable in horses. Microvascular decompression is the only causal therapy for human trigeminal neuralgia, removing a pathological contact between the trigeminal nerve and an adjacent vessel (Bennetto et al. 2007, Jannetta 1991, Paulus et al. 2003). In horses, such a pathologic contact has not yet been described. Therefore, no statement about the use of this therapy can be made. As symptomatic treatments, four different methods are described in human medicine, all of them destroying the nociceptive fibres of the trigeminal nerve root in different ways. These include percutaneous thermocoagulation (Sweet 1988), microcompression (Mullan and Lichtor 1983), glycerol injection (Hakanson 1981) and, as a newer technique, radiation therapy at the trigeminal nerve root level (Bennetto et al. 2007, Paulus et al. 2003). More than one treatment is necessary to achieve pain relief with thermocoagulation and radiation therapy (Paulus et al. 2003). Due to the higher risk in horses, these techniques are hardly practicable. According to the authors' estimation, the glycerol injection seemed to be the easiest technique to implement in equine medicine. This method has a high success rate of $95 \%$ and is the first choice therapy for elderly people due to the good tolerance (Apfelbaum 1999). However, the recurrence rate is about $40 \%$ after 17 months (Beck et al. 1986, Hakanson 1981).

The effects of this method in human medicine cannot be completely transferred to veterinary medicine due to the anatomical differences. In humans, the trigeminal ganglion is placed in a cistern which opens at only two sides, to let the trigeminal nerve in and to let the efferent nerves out. Therefore, the ganglion is separated from the remaining brain tissue. Furthermore, the cistern is crossed by trabeculae which impede drainage of injected liquids (Ferner 1948). This is different in horses, where the ganglion is placed right adjacent to the brain stem (Nickel et al. 1992). It is thus more likely that the glycerol distributes and affects other cerebral structures in the horse. In humans, the glycerol infiltrates the ganglion from all sides which again is impossible in the equine patient. In human medicine, contrast agents are used to measure the size of the cistern and to determine the exact amount of glycerol needed to completely fill the cistern (Kondziolka and Lunsford 2005). For horses, the amount of glycerol needed can only be estimated on the basis of body weight and the connected estimated size of the ganglion.

The way to the trigeminal nerve root also differs between horses and humans. While the needle can be guided subcutaneously to the oval foramen in humans, in the horse, the way inside the cranium through the guttural pouch is chosen. The fluoroscopic guidance of the needle, as commonly used in human medicine (Kondziolka and Lunsford 2005, Mullan and Lichtor 1983) cannot be performed in the horse. Therefore, in this study, computer tomographic guidance was used.

In seven out of eight cases, haemorrhage from the insertion point of the needle into the cranial cavity was induced due to 
injury of the carotid artery or the sinus petrosus. The bleeding did not require any therapy; no correlation between bleeding and subsequent complications could be detected. It was impossible to place the needle reliably avoiding injury of the artery or the venous sinus.

No incidents were recorded during anaesthesia. Upon entering the cranial cavity and passing the dura mater, blood pressure rose. In some horses, a second rise in blood pressure at the time of injection was recorded. In humans, penetration of the needle or injection of the glycerol induces a vasovagal response (with bradycardia and hypotension) in approximately $20 \%$ of the patients. Other patients show a rise in blood pressure due to pain or fear (Kondziolka and Lunsford 2005). Pain and fear can be excluded as a possible cause for blood pressure rise in this study as the horses were under general anaesthesia. Therefore, only a stress reaction is conceivable which could be triggered by noticeable changes in the extent of the sympathetic neural activity. Consistent alterations were found in a study from Lambert et al. (2006) where an intra-cisternal injection of bupivacaine induced a blood pressure rise in a human patient. Interferences with the neural activity at the brain stem level were discussed as a cause in this case. Blokkage of the baroreceptors of the brainstem is possible, as well as a direct effect of bupivacaine on the neurons arising from the nucleus tractus solitarius that induces changes in the inhibition of the sympathetic, preganglionic nerve fibres (Lambert et al. 2006). In summary, an acute activation of the sympathetic nerve fibres could also be considered as a possible cause for the rise in blood pressure in horses.

Postoperative complications were observed in two horses. The neurologic symptoms in horse two and the meningitis found during post mortem examination were ascribed to the glycerol injection. Usually, meningitis emerges via haematogenous spread or via penetrating wounds to the head (Toth et al. 2012). Meningitis due to contrast agent application has also been described (Hahn et al. 1999). The meningitis in this patient presented not only in the area of glycerol injection but also in distant areas. Therefore, an irritation caused by the glycerol is unlikely. Presumably, the injection of the glycerol induced a contamination and thereby an infection that led to meningitis. After this complication, flushing of the guttural pouch with iodine solution was initiated and no further patient developed meningoencephalitis.

Horse seven also showed neurologic symptoms after the injection. As the neurologic symptoms occurred directly after the injection, a causal relationship has to be presumed, but cannot be definitely addressed. This horse was one of the horses who received a higher amount of glycerol $(2.1 \mathrm{ml})$ due to slight backward shifting of the needle. The position of the needle during application was controlled via computed tomography and did not show significant differences in comparison with the other horses.

In all eight horses, a histological examination of the trigeminal ganglion and the efferent nerves was performed which showed a slight to serious degenerative neuropathy on the treated side of the head. In other studies on dogs and rats, degenerative changes were found in the infraorbital nerve after glycerol injection (Isik et al. 2002, Stajcic 1991). The nerve showed axonolysis and demyelination in the border regions between more and less myelinated fibres. Some of the destroyed nerve fibres were displaced by macrophages and Schwann cells (Stajcic 1991). These results are consistent with the findings on the glycerol-treated side in our study. In this study, slight degenerative changes were also found on the untreated side. The reason for these changes cannot be surely addressed, but age-related degenerations could be possible. Similar histological alterations were found in biopsies of the sural nerve in elderly people. In these cases, degeneration of myelinated and non-myelinated sensitive fibres was found more frequently with increasing age. The nerve fibres showed a reduction in fibre density and a decrease of the large, myelinated fibres. Furthermore, an extraordinary amount of empty Schwann cells (after degeneration of the axons) was found in in elderly people (Ochoa and Mair 1969, Toghi et al. 1977). These findings from human medicine are not in accordance with a study performed by Jahns et al. (2006), where age-dependent changes found in brain tissue of 100 horses were not consistent with degeneration. The changes in this study consisted of intra-neuronal ( $n=97)$, glial or extracellular lipofu$\operatorname{scin}(n=41)$, calcium deposits $(n=24)$ and hemosiderin deposits around blood vessels $(n=60)$. In two horses, Alzheimer Type Il cells were found (Jahns et al. 2006). These changes could not be retraced in our study. Due to the significant differences between treated and untreated sides, the alterations in the treated side were most likely induced by the glycerol.

\section{Manufacturers addresses}

a cp-pharma, Burgdorf, Niedersachsen, Deutschland

b Vétoquinol Chassot $\mathrm{GmbH}$, Ravensburg, Baden-Württemberg, Deutschland

c AbZ Pharma GmbH, Blaubeuren, Baden-Württemberg, Deutschland

d Baxter, Unterschleißheim, Bayern, Deutschland

e J. D. Medical Distributing Company, Phoenix, Arizona, USA

f Gould-Statham Instruments Inc., Los Angeles, California, USA

g B.Braun, Melsungen AG, Melsungen, Hessen, Deutschland

h ratiopharm GmbH, Ulm, Baden-Württemberg, Deutschland

Phillips, Hamburg, Deutschland

i Intervet International $\mathrm{GmbH}$, Unterschleißheim, Bayern, Deutschland

k Marienapotheke, Hannover, Niedersachsen, Deutschland

I Grünenthal GmbH, Aachen, Nordrhein-Westfalen, Deutschland

m Essex Tierarznei GmbH, München, Bayern, Deutschland

n WDT, Hannover, Niedersachsen, Deutschland

\section{Conflict of interest statement}

The authors declare not to be subject to any conflicts of interest in regard to drugs or technical equipment used in the present study.

\section{Animal welfare statement}

The study was declared accordingly to the German Animal Protection Law $\S 8,1$ and sanctioned by the responsible authority LAVES (Az: 33.9 42502-04-07/1347). 


\section{References}

Apfelbaum R. I. (1999) Glycerol trigeminal neurolysis. Tech. Neurosurg. 5, 225-231

Barker F. G., Jannetta P. J., Bissonette D. J., Larkins M. V., Jho H. D. (1996) The long-term outcome of microvascular decompression for trigeminal neuralgia. N. Engl. J. Med. 334, 1077-1083

Beck D. W., Olson J. J., Urig E. J. (1986) Percutaneous retrogasserian glycerol rhizotomy for treatment of trigeminal neuralgia. J. Neurosurg. 65, 28-31

Bennetto L., Patel N. K., Fuller G. (2007) Trigeminal neuralgia and its management. Brit. Med. J. 334, 210-206

Cook W. R. (1980) Headshaking in horses Part 4: Special diagnostic features. Equine Prac. 2, 7-15

Ferner H. (1948) Zur Anatomie der intrakranialen Abschnitte des Nervus trigeminus. Klin. Wschr. 26, 125-138

Hahn C. N., Mayhew J. G., MacKay R. J. (1999) Diseases of Multiple or Unknown Sites. In: Equine Medicine and Surgery, Ed.: P.T. Colohan, J.G. Mayhew, A.M. Merrit and J.N. Moore, Mosby, Inc., St. Louis, 2nd edn., 893-894

Hakanson S. (1981) Trigeminal neuralgia treated by the injection of glycerol into the trigeminal cistern. Neurosurg. 9, 638-646

Isik N., Pamir M.N., Benli K., Erbengi A., Erbengi T., Ruacan S. (2002) Experimental trigeminal glycerol injection in dogs: histopathological evaluation by light and electron microscopy. Stereotact. Funct. Neurosurg. 79, 94-106.

Jahns H., Callanan J. J., McElroy M. C., Sammin D. J., Bassett H. F. (2006) Age-related and non-age-related changes in 100 surveyed horse brains. Vet. Pathol. 43, 740-750

Jannetta P. J. (1991) Surgical treatment: microvascular decompression. In: Trigeminal neuralgia, Ed.: G.H. Fromm and B.J. Sessle, Butterworth-Heinemann, Oxford, 1th ed., 145-157

Kondziolka D., Lunsford L. D. (2005) Percutaneous retrogasserian glycerol rhizotomy for trigeminal neuralgia: technique and expectations. Neurosurg. Focus 18, 256-262.

Lambert G., Elam M., Friberg P., Lundborg C., Gao S., Berggquist J., Nitescue $P$. (2006) Acute response to intracisternal bupivacaine in patients with refractory pain of the head and neck. J. Physiol. 570, 421-428

Mullan S., Lichtor T. (1983) Percutaneous Microcompression of the Trigeminal Ganglion for Trigeminal Neuralgia. J. Neurosurg. 59, 1007-1012

\section{Einleitung}

Das idiopathische Headshaking des Pferdes ist ein komplexes, schwerwiegendes Krankheitsbild, für das bis heute keine adäquate Behandlung zur Verfügung steht. Bei dem idiopathischen Headshaking lässt sich bisher keine eindeutige Ursache feststellen. Das Krankheitsbild des Pferdes ähnelt in vielen Punkten der Trigeminusneuralgie des Menschen, eine Neuritis oder Neuralgie des Trigeminusnerven wäre folglich eine mögliche Ätiopathologie des equinen Headshakings (Cook 1980, Newton et al. 2000).

Bei der Trigeminusneuralgie des Menschen handelt es sich um eine schmerzhafte, meist einseitige Affektion des Gesichtes mit stromstoßartigem Schmerz im Versorgungsbereich eines oder mehrerer Äste des N. trigeminus. Ursächlich handelt es sich meist um ein vaskuläres Kompressionssyndrom, bei dem ein pathologischer Gefäß-Nerven-Kontakt besteht (Paulus et al. 2003). Durch die Pulsation der Arterie wird die Myelinschicht des Nerven geschädigt, es kommt zu einer segmentalen Demyelinisierung und in der Folge zu ephaptischen Fehlverbindungen (Barker et al. 1996). Bei diesem sogenannten "Kurzschlusseffektmodell" springt die Erregung von den nicht myelinisierten Fasern auf die nozizeptiven
Newton S. A., Knottenbelt D. C., Eldridge P. R. (2000) Headshaking in horses: possible aetiopathogenesis suggested by the results of diagnostic tests and several treatment regimes used in 20 cases. Equine Vet. J. 32, 208-216

Nickel R., Schummer A., Seiferle E. (1992) Gehirnnerven, Nervi craniales. In: Lehrbuch der Anatomie der Haustiere Volume IV, Nervensystem, Sinnesorgane, Endokrine Drüsen. Ed.: Nickel R., Schummer A., Seiferle E. Paul Parey, Berlin und Hamburg, 3rd edn., 305-321

Ochoa J., Mair W. G. P. (1969) Normal sural nerve in man. 2. Changes in axons and schwann cells due to ageing. Acta Neuropathol. 13, 217-223

Pannullo S. C., Lavyne M. H. (1996) Trigeminal neuralgia: neurosurgical management options. J. Am. Dent. Assoc. 127, 1635-1639

Paulus W., Evers S., May A., Steude U., Wolowski A., Pfaffenrath V. (2003) Therapy and prophylaxis of facial neuralgias and other forms of facial pain syndromes - revised recommendations of the German Society of Migraine and Headache. Schmerz 17, 74-91

Roberts V. L. H., McKane S. A., Williams A., Knottenbelt D. C. (2009) Caudal compression of the infraorbital nerve: A novel surgical technique for treatment of idiopathic headshaking and assessment of its efficacy in 24 horses. Equine Vet. J. 42, 165-170

Romeis B. (1989) Färbetechniken. In: Mikroskopische Technik. Ed.: Mulisch M., Welsch U. Urban \& Schwarzenberg, München, 17th edn., 235- 248

Stajcic Z. (1991) Effects of glycerol on the rat infraorbital nerve: an experimental study. Br. J. Oral. Maxillofac. Surg. 29, 90-93

Stienen M. N., Cadosch D., Seule M. A., Fournier J. Y., Hildebrandt G., Gautschi O. P. (2010) Trigeminal neuralgia - pathophysiology, clinical aspects and treatment. Praxis 99, 29-43

Sweet W. H. (1988) Percutaneous methods for the treatment of trigeminal neuralgia and other faciocephalic pain; comparison with microvascular decompression. Semin. Neurol. 8, 272-279

Tohgi H., Tsukagoshi H., Toyokura Y. (1977) Quantitative changes with age in normal sural nerves. Acta Neuropathol 38, 213 220

Toth B., Aleman M., Nogradi N., Madigan J. E. (2012) Meningitis and meningoencephalomyelitis in horses: 28 cases (1985-2010). J. Am. Vet. Med. Assoc. 240, 580-587
Fasern über und löst so die stromstoßartigen Schmerzen aus (Stienen et al. 2010). Zur Behandlung der Trigeminusneuralgie stehen neben der medikamentösen auch verschiedene chirurgische Therapiemöglichkeiten zur Verfügung. Davon haben die meisten das Ziel, die schmerzleitenden Ad- und C-Fasern des N. trigeminus chemisch oder mechanisch anzugreifen und dadurch die Schmerzleitung herabzusetzen (Pannullo und Lavyne 1 196). Bei der retroganglionären Glyzerolinjektion nach Hakanson (GI) wird unter Sedation das Ganglion trigeminale auf perkutanem Weg durch das Foramen ovale punktiert und steriles Glyzerol appliziert. Laut einer Studie mit 1174 Patienten liegt die Erfolgsrate der GI bei 95\% mit einer Rezidivrate von bis zu 40\% nach 17 Monaten (Kondziolka und Lunsford 2005). Das Glyzerol führt zu einer Degeneration des Nervengewebes und somit zu einer Herabsetzung der Reizweiterleitung. Als Nebenwirkung treten bei etwa der Hälfte der Patienten eine vorübergehende Hypästhesie und Hypalgesie im betroffenen Gesichtsbereich auf (Paulus et al. 2003). Obwohl beim Pferd bislang keine pathologischen Gefäß-Nerven-Kontakte nachvollzogen wurden, liefert das Kurzschlusseffektmodell eine mögliche Erklärung der Entstehung des idiopathischen Headshakings. Der Nervus mandibularis des Nervus trigemi- 
nus spielt nur selten eine Rolle beim Headshaking. Für gewöhnlich sind der Ramus infraorbitalis des Nervus maxillaris und der Ramus ethmoidalis des Nervus ophthalmicus betroffen (Newton et al. 2000). Zu den beim Pferd angewandten chirurgischen Therapiemethoden zählt die Sklerosierung des N. ethmoidalis mittels Phenol. Sie wurde 2000 von Newton at al. bei fünf Pferden durchgeführt und war in drei Fällen erfolgreich. Roberts et al. (2009) führten eine sogenannte caudale Kompression des Infraorbitalnerven durch Platinumcoils bei 24 Pferden mit idiopathischem Headshaking durch. Sie berichten von einer Erfolgsrate von $59 \%$ nach einmaliger chirurgischer Behandlung. Nachteile dieser Behandlung war eine hohe Rate an Automutilation (45.8\%) und die selektive Ausschaltung des Infraorbitalnerven (Roberts et al. 2009). Diese Behandlung kann folglich in solchen Fällen erfolgreich sein, in denen der Schmerz unmittelbar im Infraorbitalnerven entsteht. Hat der Schmerz seinen Ursprung jedoch weiter proximal, näher am Ganglion trigeminale, ist keine Besserung zu erwarten. Ziel dieser Studie war es, die Punktion des Ganglion trigeminale beim Pferd zu beschreiben und als Basis einer neven, minimal invasiven Behandlung aller Äste des Trigeminusnerven zu nutzen.

\section{Material und Methoden}

Material

Für die vorliegende Untersuchung wurden acht Pferde mit ungestörtem Allgemeinbefinden und ohne neurologische Ausfallserscheinungen herangezogen. Vier der Pferde waren Hengste, drei waren Stuten und zwei Wallache. Fünf der Pferde waren Hannoveraner, ein Pferd war ein Arabisches Vollblut, zwei Pferde wurden als "sonstige Pferde/Ponies" eingestuft. Das Alter betrug im Mittel 21,4 $( \pm 6,91)$ Jahre, das Körpergewicht (KGW) betrug im Mittel 497,5 (土90) kg.

\section{Präoperative Vorbereitungen und Anästhesie}

Die Injektion wurde unter Allgemeinanästhesie vorgenommen. Die Pferde wurde mit dem a2-Agonist Xylazin (Xylazin $2 \%)^{a}(0,08 \mathrm{mg} / \mathrm{Kg} \mathrm{KGW}$ i.v. $)$ sediert. Die Anästhesie wurde mit Ketamin (Narketan) ${ }^{b}$ (2,2 mg/kg KGW i.v.) und Diazepam (Diazep AbZ $10 \mathrm{mg}$ Ampullen)c (0,04 mg/kg KGW i.v.) induziert und mit Isofluran (Isofluran) ${ }^{d}$ in 100\% Saverstoff nach Wirkung erhalten. Während der Allgemeinanästhesie wurden die Herz- und Kreislaufparameter (Herzfrequenz, Atemfrequenz, elektrokardiographische Besonderheiten und intraarterieller Blutdruck) überwacht (Vet.Tec. Modell JAVC-2000) ${ }^{\mathrm{e}}$ und die Pferde bei Bedarf beatmet. Der mittlere arterielle Blutdruck wurde mittels eines Druckmessers (PD23ID) überwacht. Um den Blutdruck zu stabilisieren erhielten die Pferde Ringerlaktat (Ringerlaktat)g als Davertropfinfusion $(5 \mathrm{ml} / \mathrm{kg} \mathrm{KGW} / \mathrm{h}$ ) und Dobutamin (Dobutamin ratiopharm $250 \mathrm{mg}$ ) nach Wirkung $(1,2-3 \mu \mathrm{g} / \mathrm{kg} \mathrm{KGW/min).}$

Es erfolgte eine Rückenlagerung des Pferdes, der Kopf wurde symmetrisch ausgerichtet und mittels eines Vakuumkissens in Position gehalten. Die Punktionsstelle der äußeren Haut wurde antiseptisch vorbereitet. Der Luftsack wurde mit etwa 40 $\mathrm{ml}$ einer einprozentigen Povidon-Jodlösung (Braunol)g gespült.

\section{Punktionstechnik}

Als Orientierungspunkte dienten der kaudale Rand der Mandibel und der Mandibelkörper. Zur genauen Planung der Stichrichtung wurden zwei 18 Gauge Kanülen (Sterican)g zwei Zentimeter vor dem kaudalen Rand der Mandibel, einen Zentimeter unterhalb des Mandibelkörpers, in einem Winkel von $90^{\circ} \mathrm{C}$ zum Mandibelkörper lateral der Vena linguofacialis eingestochen. Die andere Kanüle wurde eineinhalb Zentimeter weiter rostral, medial der Vena linguofacialis platziert. Von der Position dieser beiden Kanülen wurde eine computertomographische Aufnahme (CT) (Phillips Tomoscan) ${ }^{i}$ angefertigt. Nach computertomographischer Beurteilung wurde die Punktionsstelle angepasst. Die definitive Punktion erfolgte mit einer Biopsienadel (Chiba-Biopsienadel)i. Die Biopsienadel wurde dann durch den Luftsack vorgeschoben und in etwa $18 \mathrm{~cm}$ Tiefe neben der Arteria carotis interna vor dem Foramen lacerum platziert. Die Position wurde nun erneut mittels CT kontrolliert. War die gewünschte Position der Kanüle erreicht, wurde die Schleimhaut durchstoßen, um die Kanüle in Position zu halten, jedoch nicht weiter vorgeschoben. Es folgte erneut eine computertomographische Kontrolle des Sitzes der Kanüle (Abb. 1). Bei korrektem Sitz wurde die Kanüle weitere eineinhalb Zentimeter vorgeführt. An dieser Stelle wurden, je nach Größe des Pferdes, zwischen 1,6 und 1,9 ml körperwarmes Glyzerol (Glycerinum anhydriacum)k in eine zufällig ausgewählte Kopfseite appliziert. Die kontralaterale Seite blieb unbehandelt und diente als Kontrolle. Sofern die Biopsienadel nach computertomographischer Kontrolle repositioniert werden musste, wurde dies als neuer Versuch gewertet.

\section{Prä- und postoperative Versorgung}

Die Tiere wurden für eine Zeitdauer von mindestens fünf Tagen mit Antibiotika und Flunixin-Meglumin versorgt. Sie erhielten am Tag der Operation bis zum nächsten Morgen Benzylpenicillin (Penicillin Grünenthal 10 Millionen I.E.) (20.000 IE/kg KGW i.v. q. 6h) sowie Gentamicin (Genta $100 \mathrm{mg} / \mathrm{ml})^{a}(6,6 / \mathrm{kg} \mathrm{KGW}$ i.v. q.d.) und Cefquinomsulfat (Cobactan 4,5\%)i (1 mg/kg KGW i.m. q.d.) für die nächsten 4 Tage. Zusätzlich erhielten die Pferde Flunixin-Meglumin (Flunidol RPa, Finadyne Paste $\left.{ }^{\mathrm{m}}\right)(1,1 \mathrm{mg} / \mathrm{kg} \mathrm{KGW}$ i.v. q.d. in den ersten zwei Tagen, anschließend 1,1 mg/kg KGW p.os. q.d. für vier weitere Tage). Die Pferde wurden sechs Wochen nach der Injektion des Glyzerols durch Pentobarbital (Release) $^{n}(0,08 \mathrm{~g} / \mathrm{kg} \mathrm{KGW} \mathrm{i.v.)} \mathrm{euthanasiert.}$

\section{Postmortale Untersuchung}

Bei den Pferden, bei denen nach der Behandlung Komplikationen auftraten, wurde eine vollständige Sektion des ganzen Körpers vorgenommen. Bei allen anderen Tieren wurde eine makroskopische Untersuchung des Luftsacks und der Eintrittsstelle in die Schädelhöhle vorgenommen. Das Ganglion trigeminale mit seinen abgehenden Nerven wurde makroskopisch und histologisch untersucht. Die Untersuchungen wurden auf der kontralateralen Seite analog durchgeführt und dienten als Kontrollgruppe. Zur histologischen Einstufung wurden Gewebeproben des Nervus trigeminus und der abgehenden Nerven aus acht verschiedenen, zuvor festgelegten Lokalisationen entnommen. Probe 1 stammte aus der unmittelbar an das Ganglion angrenzenden Pons, Probe 2 
aus dem Kerngebiet und der Austrittsstelle des Nervus trigeminus und Probe 3 aus dem Ganglion trigeminale. Die Proben 4-8 wurden aus den beiden Ästen (N. ophthalmicus, N. maxillaris und Ramus infraorbitalis) des N. trigeminus entnommen. Es erfolgte bei allen Schnitten eine HämatoxylinEosin-Färbung $(\mathrm{HE})$, bei ausgewählten Schnitten zusätzlich eine Luxol-Fast-Blue-Färbung nach einem Protokoll von Romeis (Romeis 1989). Bei der Beurteilung sind solche Fälle als geringgradig (2) einzustufen, die einzelne dilatierte Myelinscheiden zeigen, als mittelgradige (4) solche, die eine mittlere Anzahl an dilatierten Myelinscheiden und geschwollenen Axonen (Sphäroide) sowie einzelne Myelinophagen zeigen und als hochgradig (6) solche, die eine große Anzahl dieser Veränderungen (z.T. in "digestion chambers", das heißt im Längsschnitt des Nervs sieht man mehrere Myelinophagen hintereinander in derselben Myelinscheide) vorweisen. Zwischen diesen Beurteilungen sind weitere Einstufungen, nämlich gering- mittelgradig (3) und mittel- hochgradig (5) möglich. Wurden keine Veränderungen nachgewiesen, wurde dies mit 0 bewertet.

\section{Statistik}

Die Daten wurden mit Hilfe eines statistischen Programms (SAS) ausgewertet. Normalverteilte Daten wurden als Mittelwert und Standarabweichung $(x \pm s)$, nicht normalverteilte Daten als Median mit Minimal- und Maximalwert (Median; Min.-Max.) dargestellt. Für nicht normalverteilte und voneinander abhängige Daten wurde zur Berechnung von statistischen Unterschieden der Wilcoxon signed rank test angewendet. Das Signivikanzniveau wurde auf einen Wert kleiner 0.05 festgelegt.

\section{Ergebnisse}

Die Injektion des Glyzerols wurde bei fünf von acht Pferden auf der linken Kopfseite vorgenommen, bei drei von acht Pferden auf der rechten Kopfseite. Das Ganglion trigeminale wurde in allen Fällen erreicht, dazu waren zwischen einem und sieben, im Mittel vier $( \pm 1,9)$ Versuche notwendig. In sechs Fällen wurde die Kanüle lateral der Vene vorgeschoben, in zwei Fällen medial davon. In acht Fällen wurde die Kanüle medial am Zungenbein vorbeigeführt, in keinem Fall war die laterale Führungsrichtung erfolgreich. Bei Eintritt in den Luftsack wurde in drei Fällen eine Blutung vom Luftsakkboden des medialen Luftsackkompartiments ausgehend ausgelöst. Während der Applikation des Glyzerols kam es bei Pferd 7 und Pferd 8 jeweils zu einem leichten Zurückrutschen der Kanüle. Daraufhin wurde die Kanüle an ihre ursprüngliche Stelle zurück geschoben und bei beiden Pferden zusätzlich je 0,5 ml Glyzerol appliziert. Beim Entfernen der Kanüle kam es in sieben Fällen zu Einblutungen aus der Einstichstelle in der dorsalen Luftsackwand.

\section{Anästhesie und Blutdruckverlauf}

Während der Anästhesie traten in keinem Fall Komplikationen auf. Beim Vorschieben der Kanüle durch die Hirnhäute in das Ganglion trigeminale stieg bei sechs von acht Pferden der mittlere arterielle Blutdruck für die Daver von einigen Sekunden an. Bei fünf dieser sechs Pferde zeigte sich zum Zeitpunkt der Glyzerolinjektion ein erneuter Blutdruckanstieg.
Da sich der Blutdruck nach einigen Sekunden stabilisierte, wurde keine Behandlung vorgenommen. Fünf Pferde fielen zum Zeitpunkt der Injektion für einige Sekunden mit fazialem Muskelzittern auf.

\section{Postoperativer Verlauf}

Pferd 2 zeigte an Tag zwei nach der Injektion ein gestörtes Allgemeinbefinden. Dies äußerte sich in einer erhöhten Temperatur bis $41^{\circ} \mathrm{C}$ und einer geringgradig erhöhten Herz- und Atemfrequenz. An Tag 3 traten neurologische Ausfallserscheinungen hinzu, das Pferd zeigte eine gesteigerte Sensibilität und Juckreiz im Kopf/Halsbereich und einen hypermetrischen, ataktischen Bewegungsablauf. Die Stute wurde symptomatisch behandelt, der Zustand besserte sich jedoch nicht und das Pferd wurde an Tag acht nach der Operation euthanasiert und anschließend seziert.

Pferd 7 fiel nach der Aufstehphase mit neurologischen Ausfallserscheinungen auf. Diese äußerten sich in einer Kopfschiefhaltung nach links, einem linksseitigen hemifazialen Spasmus und einer generalisierten Ataxie in Form von hypermetrischen, ataktischen Bewegungen. Die Stute war ängstlich und berührungsempfindlich an beiden Seiten von Kopf und Hals. Sie wurde ebenfalls symptomatisch behandelt. Der Zustand besserte sich zusehends, so dass sie nach elf Tagen keinerlei Symptome mehr zeigte. Bei den anderen sechs Pferden traten keine neurologischen Probleme auf.

\section{Postmortale Untersuchung}

Bei Pferd 2 wurde eine fokal akzentuierte eitrige Meningitis festgestellt. Es waren histologisch keine Bakterien sichtbar. Bei Pferd 7 ließen sich in der Sektion keine Rückschlüsse auf die Ursache der neurologischen Störungen ziehen. Bei der makroskopischen Beurteilung des Luftsacks, der Einstichstelle im Luftsack und des Ganglion trigeminale fielen bei keinem der Pferde Unterschiede zwischen behandelter und nicht behandelter Seite auf.

\section{Histologie}

In zwei Fällen zeigten sich auf der behandelten Seite geringgradige (Score 2, Pferde 6 und 8), in weiteren einem Fall gering- mittelgradige (Score 3, Pferd 3), in einem Fall mittelgradige (Score 4, Pferde 1 und 4) und in zwei Fällen hochgradige (Score 6, Pferde 5 und 7) Veränderungen im Sinne einer degenerativen Neuropathie. Auf der unbehandelten Seite wurde keine $(n=2)$, an einzelnen Entnahmestellen geringgradige $(n=5)$ degenerative Veränderungen vorgefunden. Die neurologischen Veränderungen waren auf der injizierten Seite $(11 ; 6-32)$ signifikant schwerwiegender $(p=0,018)$ als auf der nicht injizierten Seite $(2 ; 0-4)$. Pferd 2 kann aufgrund der festgestellten eitrigen Meningitis hinsichtlich einer stattgefundenen Degeneration nicht hinreichend beurteilt werden.

\section{Diskussion}

Im Rahmen dieser Studie waren vor allem die Durchführbarkeit der Glyzerolinjektion, die auftretenden Nebenwirkungen und die histologischen Veränderungen von Interesse. 
In der Humanmedizin stehen zur Behandlung der Trigeminusneuralgie verschiedene chirurgische Therapiemöglichkeiten zur Verfügung (Bennetto et al. 2007, Jannetta 1991, Paulus et al. 2003). Beim Pferd sind aus verschiedenen Gründen nicht alle dieser Versuche durchführbar. Bei der mikrovaskulären Dekompression handelt es sich um die einzige beim Menschen angewandte kausale Therapie, die einen pathologischen Kontakt zwischen Trigeminusnerv und einem Gefäß behebt (Jannetta 1991). Da beim Pferd bislang keine pathologischen Gefäß-Nerven Kontakte beschrieben sind, kann derzeit keine Aussage über den Einsatz einer solchen Therapie gemacht werden. Als symptomatische Behandlungen, die auf unterschiedliche Arten die schmerzleitenden Fasern des Ganglions angreifen, stehen in der Humanmedizin vier verschiedene Therapien zur Verfügung. Hierzu zählen die Thermokoagulation nach Sweet (1988), die Ballonkompression nach Mullan und Lichtor (1983), die Glyzerolinjektion nach Hakanson (1981) und als nevere Behandlung die Strahlentherapie (Bennetto et al. 2007, Paulus et al. 2003). Bei der Thermokoagulation und auch bei der Strahlentherapie sind, neben speziellen Geräten, in der Regel mehrere Sitzungen nötig, um eine Schmerzfreiheit zu erreichen (Paulus et al. 2003). Da die Durchführung beim Pferd vergleichsweise risikoreich erscheint, sind die drei erstgenannten Eingriffe schwierig zu realisieren.

Die Glyzerolinjektion nach Hakanson (1981) ist nach eigener Einschätzung somit die beim Pferd am einfachsten umzusetzende Methode. Sie bietet beim Menschen mit 95\% eine hohe Erfolgsrate und ist auf Grund der guten Toleranz gerade bei älteren Patienten die Methode der ersten Wahl (Apfelbaum 1999). Allerdings liegt die Rezidivrate 17 Monate nach der Behandlung bei 40\% (Beck et al. 1986, Hakanson 1981). In Bezug auf die Vergleichbarkeit erschwerend sind die anatomischen Gegebenheiten bei Mensch und Pferd zu sehen. Beim Menschen liegt das Ganglion trigeminale in einer Zisterne, die sich nur an zwei Stellen öffnet. Einmal, um den Nervus trigeminus eintreten zu lassen und ein zweites Mal, um die abgehenden Nerven austreten zu lassen. Dadurch ist das Ganglion vom umliegenden Gewebe abgeschirmt. Zusätzlich ist die Zisterne von Trabekeln durchzogen, die das Abfließen einer injizierten Flüssigkeit in Richtung Gehirn nochmals erschweren (Ferner 1948). Dies ist beim Pferd nicht der Fall. Hier liegt das Ganglion dem Stammhirn unmittelbar an (Nickel et al. 1992). Somit ist die Wahrscheinlichkeit, dass das Glyzerol neben dem Ganglion noch andere zerebrale Strukturen in Mitleidenschaft zieht, beim Pferd erheblich größer. Außerdem erreicht das Glyzerol beim Menschen das Ganglion von allen Seiten, was beim Pferd wiederum nicht möglich ist, da das Ganglion mit einer Seite dem Stammhirn anliegt. In der Humanmedizin werden Kontrastmittel eingesetzt, um die Größe der Zisterne und somit die genaue Menge an Glyzerol zu ermitteln, die nötig ist, um die Zisterne auszufüllen (Kondziolka und Lunsford 2005). Beim Pferd kann die Menge nur anhand des Gewichts des Tieres und der damit assoziierten Größe des Ganglions geschätz† werden. Auch das Gewinnen von Zerebrospinalflüssigkeit (Kondziolka und Lunsford 2005) kann beim Pferd nicht zur Kontrolle der korrekten Position genutzt werden.

Der Weg, den die Kanüle zum Ganglion trigeminale nehmen muss, unterscheidet sich bei Mensch und Pferd. Während die Kanüle beim Menschen subkutan zum Foramen ovale vorge- schoben wir (Bennetto et al. 2007, Kondziolka und Lunsford 2005, Paulus et al. 2003), wird beim Pferd der Weg zum Ganglion trigeminale innerhalb des knöchernen Schädels durch den Luftsack gewählt. Eine fluoroskopische Darstellung des Kanülenverlaufs, wie in der Humanmedizin üblich (Kondziolka und Lunsford 2005, Mullan und Lichtor 1983), ist daher beim Pferd nicht möglich. Deshalb wurde beim Pferd die Computertomographie zur Positionskontrolle gewählt.

Beim Platzieren der Kanüle wurde in vier Fällen die A. carotis interna oder der Sinus petrosus ventralis perforiert, in fünf Fällen verlief die Kanüle zwischen den Schlingen der Arterie und verletzte diese nicht. Die entstehende Blutung wurde nicht therapiert, es wurde kein Zusammenhang zwischen der Blutung in den Luftsack und einer nachfolgenden Komplikation festgestellt. Es war nicht möglich, eine Stichführung festzulegen, mit der eine Punktion der Arterie oder des venösen Sinus ausgeschlossen werden konnte.

Während der Allgemeinanästhesie traten keine Zwischenfälle auf. Zum Zeitpunkt des Eintretens der Kanüle in das zerebrale Gewebe, bei manchen Pferden erneut zum Zeitpunkt der Injektion des Glyzerols, wurde ein Blutdruckanstieg verzeichnet. Beim Menschen kommt es in etwa 20\% der Fälle zu einer vasovagalen Antwort (mit Bradykardie und Hypotension) auf die Penetration der Kanüle oder die Glyzerolinjektion. Andere Patienten zeigen einen Blutdruckanstieg, der ebenfalls durch Schmerz oder Angst ausgelöst wird (Kondziolka und Lunsford 2005). Da die Komponente der Angst beim Pferd unter Allgemeinanästhesie auszuschließen ist, käme nur eine Stressreaktion in Frage. Dies könnte auf erhebliche Veränderungen im Ausmaß der sympathischen nervalen Aktivität beruhen. Ähnliches wurde in einer Untersuchung von Lambert et al. (2006) vermutet. Hier kam es nach einer intrazisternalen Injektion von Bupivacain beim Menschen zu einem Blutdruckanstieg. Als Ursache dieser hämodynamischen Konsequenz wurde von einer Interferenz mit der neuronalen Aktivität auf Stammhirnhöhe ausgegangen: Eine Blockade der Barorezeptoren der Gehirnnerven ist ebenso denkbar wie ein direkter Effekt des Bupivacains auf die Neurone, die vom Nucleus tractus solitarius ausgehen und auf diesem Weg eine Veränderung der Inhibition der sympathischen, präganglionären Fasern hervorruft (Lambert et al. 2006). Zusammengefasst kommt auch beim Pferd als Ursache des Blutdruckanstiegs eine akute Aktivierung sympathischer Nerven in Frage.

Bei zwei Pferden kam es im postoperativen Verlauf zu Komplikationen. Die bei Pferd 2 beobachteten neurologischen Symptome und die in der Sektion festgestellte Meningoenzephalitis werden auf die Glyzerolinjektion zurückgeführt. Gewöhnlich entsteht eine Meningoenzephalitis auf hämatogenem Infektionsweg oder durch penetrierende Wunden im Bereich des Kopfes (Toth et al. 2012). Eine durch Chemikalien ausgelöste Meningitis wurde nach Kontrastmittelmyelographien ebenfalls beobachtet (Hahn et al. 1999). Da die Meningitis in dieser Studie nicht nur im Bereich des injizierten Glyzerols bestand, sondern auch andere Bereiche betraf, ist eine Reizung durch das Glyzerol nicht wahrscheinlich. Vermutlich handelt es sich um eine Infektion, ausgelöst durch eine Kontamination, die durch die Injektion hervorgerufen wurde. Nach dieser Komplikation wurde die Spülung des Luftsacks mit einer lodlösung eingeführt und kein weiterer Patient entwickelte eine Meningoenzephalitis. 
Auch Pferd 7 fiel nach der Injektion mit neurologischen Symptomen auf. Auf Grund des Auftretens der neurologischen Symptome im unmittelbaren Anschluss an die Injektion muss hier ein ursächlicher Zusammenhang gesehen werden. Dieses Pferd erhielt eine etwas größere Menge Glyzerol $(2,1 \mathrm{ml})$, da die Kanüle bei der Applikation leicht zurück rutschte. Die Platzierung der Kanüle erfolgte analog derjenigen der anderen Versuchspferde. Unterschiede im Vergleich zu den übrigen Pferden auf.

Bei allen acht Pferden wurde auf der injizierten und der kontralateralen Seite eine histologische Untersuchung des Ganglion trigeminale und der abgehenden Nerven vorgenommen. Bei allen Pferden zeigte sich auf der injizierten Seite eine degenerative Neuropathie, abgestuft von gering- bis zu hochgradigen Veränderungen der Nerven. In verschiedenen Untersuchungen waren nach einer Glyzerolinjektion an den Infraorbitalnerven ebenfalls degenerative Veränderung festgestellt worden (Isik et al. 2002, Stajcic 1991). Diese zeigten sich in Axonolyse und Demyelinisierung im Randbereich des Nerven. Es waren sowohl stärker und weniger stark myelinisierte Fasern betroffen. Einige der zerstörten Nervenfasern waren durch Makrophagen oder Schwannsche Zellen ersetzt (Stajcic 1991). Diese Ergebnisse gleichen den in dieser Studie auf der behandelten Kopfseite erhobenen Befunden. Zum Teil fanden sich auch auf der kontralateralen, unbehandelten Seite geringgradige degenerative Veränderungen. Da das Glyzerol dort keine histologischen Veränderungen hervorgerufen haben kann, ist die Ursache der Veränderungen nicht sicher zu bestimmen. Möglich wäre eine altersbedingte Degeneration. Dies wurde in einer histologischen Untersuchung von Biopsien des Nervus suralis bei älteren Menschen festgestellt. Hier konnte eine Degeneration sowohl von myelinisierten als auch nicht myelinisierten sensiblen Fasern mit zunehmendem Alter in zunehmender Häufigkeit festgestellt werden. Sie zeigte sich in einer Reduktion der Faserdichte und einer Abnahme von großen, myeli- nisierten Fasern. In besonderem Ausmaß wurden bei älteren Menschen "leere", nach einer Degeneration der Axone entstandene Schwannsche Zellen, gefunden (Ochoa und Mair 1969, Tohgi et al. 1977). Diese Befunde stehen im Kontrast zu den Befunden von Jahns et al. (2006), wo die in einer Studie an 100 Pferdegehirnen festgestellten physiologischen Veränderungen des Nervengewebes im Alter nicht denen einer Degeneration entsprechen. Die Veränderungen bestehen in dieser Studie aus intraneuronalen $(n=97)$, glialen oder extrazellulären Lipofuscin $(n=41)$ und Calcium $(n=24)$ Ablagerungen und Haemosiderin Ablagerungen rund um Blutgefäße $(n=60)$. Bei zwei Pferden wurden Alzheimer Typ II Zellen gefunden. Diese Veränderungen konnten hier nicht nachvollzogen werden. Auf Grund der signifikanten Unterschiede zwischen der injizierten Seite und der Kontrollseite wurden die Veränderungen in dieser Studie auf der behandelten Seite mit großer Sicherheit durch das Glyzerol hervorgerufen.

Zusammenfassend zeigt diese Studie, dass eine Umsetzung der Glyzerolinjektion in das Ganglion trigeminale am Pferd ohne eine signifikante Anzahl an Komplikationen möglich ist. Verschiedene anatomische Gegebenheiten bei Mensch und Pferd bedingen zwangsläufig einige Unterschiede in der Vorgehensweise. Der Kanülenverlauf ist beim Pferd schwieriger zu kontrollieren, da die Möglichkeit der fluoroskopischen Kontrolle nicht gegeben ist. Die CT-geleitete Steuerung der Kanüle beim Pferd ist praktikabel. Da die Glyzerolinjektion bisher nur an gesunden Pferden vorgenommen wurde, ist die Wirkung, das heißt eine Linderung des Headshakings, nicht überprüfbar. Die histologischen Veränderungen belegen eine Degeneration des Nervengewebes und implizieren somit eine verminderte Leiffähigkeit. Vor allem im Hinblick darauf, dass zurzeit keine erfolgreiche Behandlungsmethode für das Headshaking beim Pferd existiert, ist die vorliegende Untersuchung als Grundlage für eine direkte, minimal invasive Therapie am Ganglion trigeminale zu sehen. 